\title{
Wogonin affects proliferation and the energy metabolism of SGC-7901 and A549 cells
}

\author{
SHU-JING WANG, JIAN-KAI ZHAO, SHUANG REN, WEI-WEI SUN, WEN-JUN ZHANG and JIA-NING ZHANG
}

College of Pharmacy, Harbin University of Commerce, Harbin, Heilongjiang 150076, P.R. China

Received December 17, 2017; Accepted October 3, 2018

DOI: $10.3892 /$ etm.2018.7023

\begin{abstract}
Many studies have focused on the identification of therapeutic targets for the treatment of certain types of cancer. Wogonin is a natural flavonoid compound that exhibits a potent anti-cancer effect. The underlying mechanism of wogonin may therefore reveal an effective way to identify novel therapeutic targets. In the current study, growth curves and MTT assays were performed to determine the effects of wogonin in human gastric cancer cells (SGC-7901) and human lung adenocarcinoma cells (A549), respectively. Changes in morphology were observed using hematoxylin and eosin (H\&E) staining. The activities of key enzymes in the glycolysis and tricarboxylic acid cycle were measured using spectrophotometry. Western blot analysis was performed to determine the expression levels of hypoxia inducible factor- $1 \alpha$ (HIF-1 $\alpha)$ and monocarboxylate transporter-4 (MCT-4). Wogonin inhibited cell proliferation in a time- and dose-dependent manner in SGC-7901 and A549 cells. H\&E staining suggested that wogonin induced cell morphology changes. In SGC-7901 cells, lactate dehydrogenase (LDH) and succinate dehydrogenase (SDH) activities and adenosine triphosphate (ATP) generation were decreased significantly by wogonin treatment compared with the untreated control. In A549 cells, wogonin significantly reduced LDH activity, but exhibited no significant effects on kinase activities or ATP generation. Furthermore, wogonin significantly decreased HIF-1 $\alpha$ and MCT-4 protein expression in SGC-7901 cells, but not in A549 cells. The results demonstrated that wogonin inhibited the energy metabolism, cell proliferation and angiogenesis in SGC-7901 and A549 cells by negatively regulating HIF-1 $\alpha$ and MCT-4 expression. The differential regulatory roles of wogonin in metabolism-associated enzymes in human gastric cancer and lung adenocarcinoma cells indicated its various antitumor mechanisms. The different metabolic regulatory
\end{abstract}

Correspondence to: Dr Jia-Ning Zhang, College of Pharmacy, Harbin University of Commerce, 138 Tongda Street, Harbin, Heilongjiang 150076, P.R. China

E-mail: mzhangjianing1224@163.com

Key words: wogonin, energy metabolism, enzyme, adenosine triphosphate, SGC-7901 cells, A549 cells mechanisms exhibited by wogonin in different tumor tissues should therefore be considered for antitumor therapy.

\section{Introduction}

Wogonin is a flavonoid compound first isolated from Scutellaria baicalensis and is used in Chinese herbal medicine (1). It has been recognized as a potent anticancer agent due to its broad toxicity in various types of cancer cell lines, including human breast cancer, liver cancer, lung cancer and human gastric cancer cells (2-5). The underlying mechanisms of the growth-suppressive effects of wogonin on tumor cells are considered to be associated with inhibition of cell proliferation (6), induction of apoptosis (7), antiangiogenesis (8-12) and promotive effects on tumor cell differentiation (13). In addition, wogonin further exhibited pharmacologic properties, including neuroprotective, antiviral, anti-inflammatory and antioxyradical effects (14-16). Previously, various studies focused on exploring the underlying cellular pathways responsible for the energy metabolism in tumorigenesis. Increased catabolic glucose metabolism is one of the primary metabolic changes observed in proliferating cells (17). The shift in energy production in tumor cells from oxidative phosphorylation to glycolysis, regardless of the oxygen concentration, is a phenomenon termed 'Warburg effect' (18). Although the mechanisms and benefits of this metabolic behavior in tumor cells remain unclear, disturbance of the glycolysis emerges as a promising strategy for cancer therapy $(19,20)$. The effects of wogonin on antiproliferative and apoptotic activities have been documented using various human cancer cells; however, its effects on energy metabolism-associated enzymes and adenosine triphosphate (ATP) generation in SGC-7901 and A549, human gastric cancer and human lung adenocarcinoma cell lines, respectively, remains to be elucidated.

Tumor cells have a unique aerobic glycolysis. Abnormal changes in glucose metabolism may exist in tumor cells and even in the presence of oxygen, glucose metabolism is transformed from oxidative phosphorylation to glycolysis, which consumes large quantities of glucose and generates lactic acid (21). In line with these characteristics, the present study attempted to evaluate different effects of wogonin on proliferation inhibition of SGC-7901 and A549 cells and further explored the sensitivity of these cell lines to wogonin, based on changes observed for various enzymes involved in the energy metabolism. The results suggested that in SGC-7901 
cells, wogonin inhibited the growth of tumor cells by interfering with the energy metabolism. Furthermore, decreased hypoxia inducible factor- $1 \alpha(\mathrm{HIF}-1 \alpha)$ and monocarboxylate transporter-4 (MCT-4) expression induced by wogonin may be partially responsible for inhibitory effects in the tumor metabolism. In A549 cells, wogonin demonstrated little influence on the energy metabolism. Since sensitivity to wogonin may be not the same in certain types of tumor cell, different anti-tumor therapy should therefore be considered when wogonin is used alone or in combination. The present study aimed to provide a guide for further studies on targeted therapy for different tumors types.

\section{Materials and methods}

Reagents and antibodies. Wogonin (Chengdu Institute of Biology, Chinese Academy of Science, Chengdu, China) was dissolved in dimethyl sulfoxide (DMSO; $100 \mathrm{mg} / \mathrm{ml}$ ) and stored at $-20^{\circ} \mathrm{C}$. The solution was diluted as required using RPMI-1640 medium. 5-Fluorouracil (5-Fu) and MTT were purchased from Sigma-Aldrich (Merck KGaA, Darmstadt, Germany). SGC-7901 and A549 cell lines were obtained from the Institute of Biochemistry and Cell Biology, Chinese Academy of Sciences (Shanghai, China). RPMI-1640 medium, Fetal Bovine Serum (cat. no. 16000-044) and trypsin-EDTA $0.25 \%$ (cat. no. 25200-072) were purchased from Thermo Fisher Scientific, Inc. (Waltham, MA, USA). Bicinchoninic acid (BCA) Protein Assay kit (cat. no. P0010), RIPA Lysis Buffer (cat. no. P0013B) and Trypan blue Staining Cell Viability Assay kit (cat. no. C0011) were purchased from Beyotime Institute of Biotechnology (Shanghai, China). Hexokinase (HK) assay kit (cat. no. A007-1), pyruvate kinase (PK) assay kit (cat. no. A076-1), lactate dehydrogenase (LDH) assay kit (cat. no. A020-1) and succinate dehydrogenase (SDH) activity assay kit (cat. no. A022). ATP assay kit (cat. no. A059-1) and Hematoxylin-Eosin stain kit (cat. no. D006) were obtained from Nanjing Jiancheng Bioengineering Institute (Nanjing, Jiangsu, China). Rabbit HIF-1 $\alpha$ (cat. no. PB0245) and MCT-4 (cat. no. PB0269) antibodies were obtained from Boster Biological Technology (Pleasanton, CA, USA). Mouse $\beta$-actin (cat. no. 60008-1), horseradish peroxidase-conjugated goat anti-rabbit IgG (cat. no. SA00001-2) and goat anti-mouse IgG (cat. no. SA00001-1) antibodies were obtained from ProteinTech Group, Inc. (Chicago, IL, USA). The diaminobenzidine (DAB) kit (cat. no. ZLI-9018) was obtained from Beijing Zhongshan Jinqiao Biotechnology Co., Ltd. (OriGene Technologies, Inc., Beijing. China). The enhanced chemiluminescence (ECL) kit (cat. no. 32109) was obtained from Thermo Fisher Scientific, Inc.

Measurements of cell growth and viability. SGC-7901 and A549 cells were cultured in RPMI-1640 medium supplemented with $10 \% \mathrm{FBS}$ and $1 \%$ penicillin/streptomycin in a humidified incubator in an atmosphere of $5 \% \mathrm{CO}_{2}$ at $37^{\circ} \mathrm{C}$ as previously described $(22,23)$. Cells were seeded in 96-well plates at a density of $5 \times 10^{4}$ cells/well and incubated with $5 \%$ $\mathrm{CO}_{2}$ at $37^{\circ} \mathrm{C}$ for $24 \mathrm{~h}$. Subsequently, the cells were treated with wogonin at varying concentrations $(5,10,15,20,25$ and $30 \mu \mathrm{g} / \mathrm{ml}$ ) at $37^{\circ} \mathrm{C}$ for $48 \mathrm{~h}$. An untreated control experiment was also performed. Cell viability was assessed by adding
MTT in PBS to a final concentration of $5 \mathrm{mg} / \mathrm{ml}$. Plates were incubated at $37^{\circ} \mathrm{C}$ for a further $4 \mathrm{~h}$. DMSO $(150 \mu \mathrm{l})$ was added to each well and incubated for $10 \mathrm{~min}$ at room temperature. The amount of MTT-formazan was directly proportional to the number of living cells and was determined by measuring the optical density at $490 \mathrm{~nm}$. Cell survival rate was calculated using the following equation: Cell survival rate $(\%)=($ Average $\mathrm{OD}_{\text {wogonin }}$ - Average $\left.\mathrm{OD}_{\text {control }}\right) /\left(\right.$ Average $\mathrm{OD}_{\text {control }}$ - Average $\left.\mathrm{OD}_{\text {blank }}\right) \times 100 \% . \mathrm{IC}_{50}$ were calculated using SPSS 20.0 (IBM Corp., Armonk, NY, USA). Each experiment was repeated 4 times.

Trypan blue exclusion assay. SGC-7901 and A549 cells were seeded into 24 -well plates at a density of $5 \times 10^{4}$ cells/well and incubated with $5 \% \mathrm{CO}_{2}$ at $37^{\circ} \mathrm{C}$ for $24 \mathrm{~h}$. Following pretreatment with wogonin $(15 \mu \mathrm{g} / \mathrm{ml})$ or 5 -Fu $(10 \mu \mathrm{g} / \mathrm{ml})$ at $37^{\circ} \mathrm{C}$ for $24 \mathrm{~h}$, a cell suspension was prepared at a suitable dilution $\left(1.0 \times 10^{5}\right.$ cells $\left./ \mathrm{ml}\right)$ in PBS. A total of $50 \mu \mathrm{l}$ of cell suspension was taken and mixed with an equal volume of $0.4 \%$ Trypan blue. The number of viable cells was counted under a light microscope at a magnification of $\mathrm{x} 20$ once daily for 7 days, and the growth curve was constructed. An untreated control group was analyzed additionally. Each experiment was repeated 4 times and the results were expressed as the mean \pm standard deviation for each treatment group.

Cell morphological assessment. SGC-7901 and A549 cells were seeded at a density of $5 \times 10^{4}$ cells/well on coverslips, which were placed in 6-well plates and incubated with $5 \%$ $\mathrm{CO}_{2}$ at $37^{\circ} \mathrm{C}$ for $24 \mathrm{~h}$. Subsequently, the cells were treated with wogonin $(15 \mu \mathrm{g} / \mathrm{ml})$ at $37^{\circ} \mathrm{C}$ for $48 \mathrm{~h}$. An untreated control experiment was performed in parallel. Cells were washed with ice-cold PBS and fixed with $95 \%$ ethanol for $15 \mathrm{~min}$ at room temperature, followed by staining with hematoxylin $(5 \mathrm{mg} / \mathrm{ml})$ for $5 \mathrm{~min}$ and eosin $(5 \mathrm{mg} / \mathrm{ml})$ for $3 \mathrm{~min}$ at room temperature. Then the coverslips were then dehydrated with graded ethanol for 1-2 sec at room temperature and soaked in xylene for $5 \mathrm{~min}$, mounted at room temperature and dried at $37^{\circ} \mathrm{C}$ for $24 \mathrm{~h}$. Morphological changes of the cells were observed under a light microscope at a magnification of $\mathrm{x} 40$. Furthermore, the number of cells in each group were counted at a magnification of x20 and evaluated. Each experiment was repeated 4 times.

Enzyme activity assays. After SGC-7901 and A549 cells were seeded into 6-well plates at a density of $5 \times 10^{5}$ cells/well, cells were pretreated with wogonin $(15 \mu \mathrm{g} / \mathrm{ml})$ for $48 \mathrm{~h}$ at $37^{\circ} \mathrm{C}$. An untreated control experiment was also performed. Following pretreatment, cells were trypsinized with Trypsin-EDTA and suspended in $0.9 \%$ physiological saline, then centrifuged at $2,000 \times \mathrm{g}$ for $5 \mathrm{~min}$ at $4^{\circ} \mathrm{C}$. HK, PK, LDH and SDH activities were assessed with activity assay kits by measuring the absorbance at 340, 440 and $600 \mathrm{~nm}$, respectively. Enzyme activities were normalized against the protein concentration, determined using the BCA Protein Assay kit at $562 \mathrm{~nm}$. Each experiment was repeated 4 times.

Western blot analysis. HIF-1 $\alpha$ and MCT-4 expression were examined by western blot analysis. After SGC-7901 and A549 cells reached a confluence of $70 \%$, they were incubated with wogonin $(15 \mu \mathrm{g} / \mathrm{ml})$ for $48 \mathrm{~h}$ with $5 \% \mathrm{CO}_{2}$ at $37^{\circ} \mathrm{C}$ in cell culture 
flasks. Cells were then washed with ice-cold PBS 3 times and the total protein was extracted with RIPA Lysis Buffer. Samples were then centrifuged at $13,500 \mathrm{x} \mathrm{g}$ for $15 \mathrm{~min}$ at $4^{\circ} \mathrm{C}$ to remove cell debris. An untreated control experiment was also performed. The protein concentration was measured using the BCA Protein Assay kit. Protein $(\sim 30 \mu \mathrm{g})$ was loaded and separated on $10 \%$ SDS-PAGE gels and transferred to nitrocellulose membranes. Following $1 \mathrm{~h}$ of blocking with $5 \%$ non-fat dried milk in Tris-buffered saline containing $0.1 \%$ Tween-20 (TBS-T) at room temperature, the membranes were incubated with primary antibodies with gentle shaking overnight at $4^{\circ} \mathrm{C}$; HIF-1 $\alpha$ (1:100), MCT-4 (1:100) and $\beta$-actin $(1: 1,000)$ prepared in $5 \%$ non-fat dried milk in TBS-T. Membranes were further incubated with secondary antibodies for $1 \mathrm{~h}$ at room temperature, then developed using an ECL kit and scanned densitometry. The band densities were quantified via densitometry using Quantity One Software 4.4 (Bio-Rad Laboratories, Inc., Hercules, CA, USA). The intensities of the protein bands were normalized against $\beta$-actin. Each experiment was repeated 4 times.

Statistical analysis. Data are expressed as mean \pm standard deviation. Statistical analysis was performed with SPSS (version 20.0; IBM Corp., Armonk, NY, USA). Differences between the conditions tested were identified using one-way analysis of variance and differences among groups were analyzed for significance using a Tukey's test. Comparisons between two groups were performed using the Student's t-test. $\mathrm{P}<0.05$ was considered to indicate a statistically significant difference.

\section{Results}

Wogonin affects the proliferation of SGC-7901 and A549 cells. To evaluate the effect of wogonin on cell proliferation, SGC-7901 and A549 cells were treated with varying concentrations of wogonin and viability was evaluated by MTT assays. As presented in Fig. 1A, the results suggested that the inhibition rates of wogonin in A549 cells were stable at high concentrations $(10-30 \mu \mathrm{g} / \mathrm{ml})$. Measured rates were all similar to the $\mathrm{IC}_{50}(18.17 \mu \mathrm{g} / \mathrm{ml})$ for A549 cells. To achieve high efficiency and low toxicity, $15 \mu \mathrm{g} / \mathrm{ml}$ wogonin were used in subsequent experiments with A549 cells. In SGC-7901 cells, the inhibitory effect of wogonin on cell proliferation was dose-dependent between 5 and $20 \mu \mathrm{g} / \mathrm{ml}$. Although the inhibitory rate was higher at $20 \mu \mathrm{g} / \mathrm{ml}$ compared with the $15 \mu \mathrm{g} / \mathrm{ml}$ treatment, to achieve lower toxicity and to be consistent with the A549 cells, $15 \mu \mathrm{g} / \mathrm{ml}$ wogonin in SGC-7901 cells was selected for further research. The inhibitory rates of SGC-7901 and A549 cells following wogonin treatment $(15 \mu \mathrm{g} / \mathrm{ml})$ were $35.00 \pm 0.12$ and $54.17 \pm 0.24 \%$, respectively, indicating a stronger inhibitory effect of wogonin on A549 cell proliferation compared with SGC-7901 cells.

To investigate whether the effect of wogonin on cell proliferation was time-dependent, SGC-7901 and A549 cells were treated with $15 \mu \mathrm{g} / \mathrm{ml}$ wogonin for 7 days and the cell numbers were counted daily. Growth curves were prepared to describe the effect of wogonin on cell proliferation over time. As presented in Fig. 1B, wogonin decreased the cell proliferation in the cell lines in a time-dependent manner compared with the untreated control. Treatment with wogonin markedly decreased cell number in a time-dependent manner in each cell line, which was similar in strength to the effect exhibited by $10 \mu \mathrm{g} / \mathrm{ml} 5$-Fluorouracil (5-Fu). 5-Fu is a potent anti-tumor agent that affects pyrimidine synthesis by inhibiting thymidylate synthetase, thus depleting intracellular dTTP pools (24). The results suggested that wogonin significantly inhibited the proliferation of SGC-7901 and A549 cells over time compared with an untreated control.

Cell morphological assessment following wogonin treatment. Morphological changes induced by Wogonin $(15 \mu \mathrm{g} / \mathrm{ml})$ were observed by $H \& E$ staining. As presented in Fig. 2, the majority of treated cells exhibited a round in shape, loss of cell volume, hyperchromatic nuclei and cytoplasm agglutination compared with the untreated controls (Fig. 2A-D). Compared with controls, the cell numbers were significantly decreased following treatment with wogonin in SGC-7901 and A549 cells (Fig. 2E and F). These results indicated that wogonin may induce cell morphological changes in the studied cell lines.

Wogonin affects ATP generation and the activities of energy metabolism-associated enzymes. To investigate the effects of wogonin on energy metabolism, activities of enzymes participating in glucose anaerobic glycolysis, including HK, PK and $\mathrm{LDH}$, and the activity of SDH, a contributor to the tricarboxylic acid cycle (TAC), were measured. As presented in Table I, SDH activity and ATP levels were significantly decreased by wogonin in SGC-7901 cells when compared with the untreated control $(\mathrm{P}<0.05)$. The inhibitory effect of wogonin significantly impacted on LDH activity when compared to the untreated control $(\mathrm{P}<0.01)$. Compared with the controls, A549 cells treated with wogonin significantly inhibited LDH activity $(\mathrm{P}<0.01)$ and ATP content was decreased $(\mathrm{P}<0.05)$. HK, SDH and $\mathrm{PK}$ activities were not significantly affected. The results indicated that wogonin may affect lactic acid and cell energy generation in SGC-7901 cells. Furthermore, wogonin treatment only regulated lactic acid and ATP generation in A549 cells.

Wogonin affects HIF-1 $\alpha$ and MCT-4 expressions. To further investigate the effect of wogonin on energy metabolism-associated enzymes, HIF-1 $\alpha$ and MCT-4 expression were determined by western blot. As presented in Fig. 3, following treatment with wogonin for $48 \mathrm{~h}, \mathrm{HIF}-1 \alpha$ and MCT-4 expression significantly decreased in SGC-7901 cells compared with the control $(\mathrm{P}<0.01$; Fig. $3 \mathrm{~A})$, but no significant changes were observed in A549 cells (Fig. 3B).

\section{Discussion}

Scutellaria has been used in Chinese herbal medicine for the treatment of inflammation, cancer, allergies and bacterial and viral infections of the respiratory and gastrointestinal tract (25). Wogonin is one of the effective compounds extracted from Scutellaria, exhibiting multiple pharmacological effects, including cytotoxic effects in human cancer cell lines, inhibitory effects on tumor angiogenesis and neoplasm metastasis (26).

The present study performed MTT assays to measure the inhibitory rates of wogonin in several cancer cell lines and it 

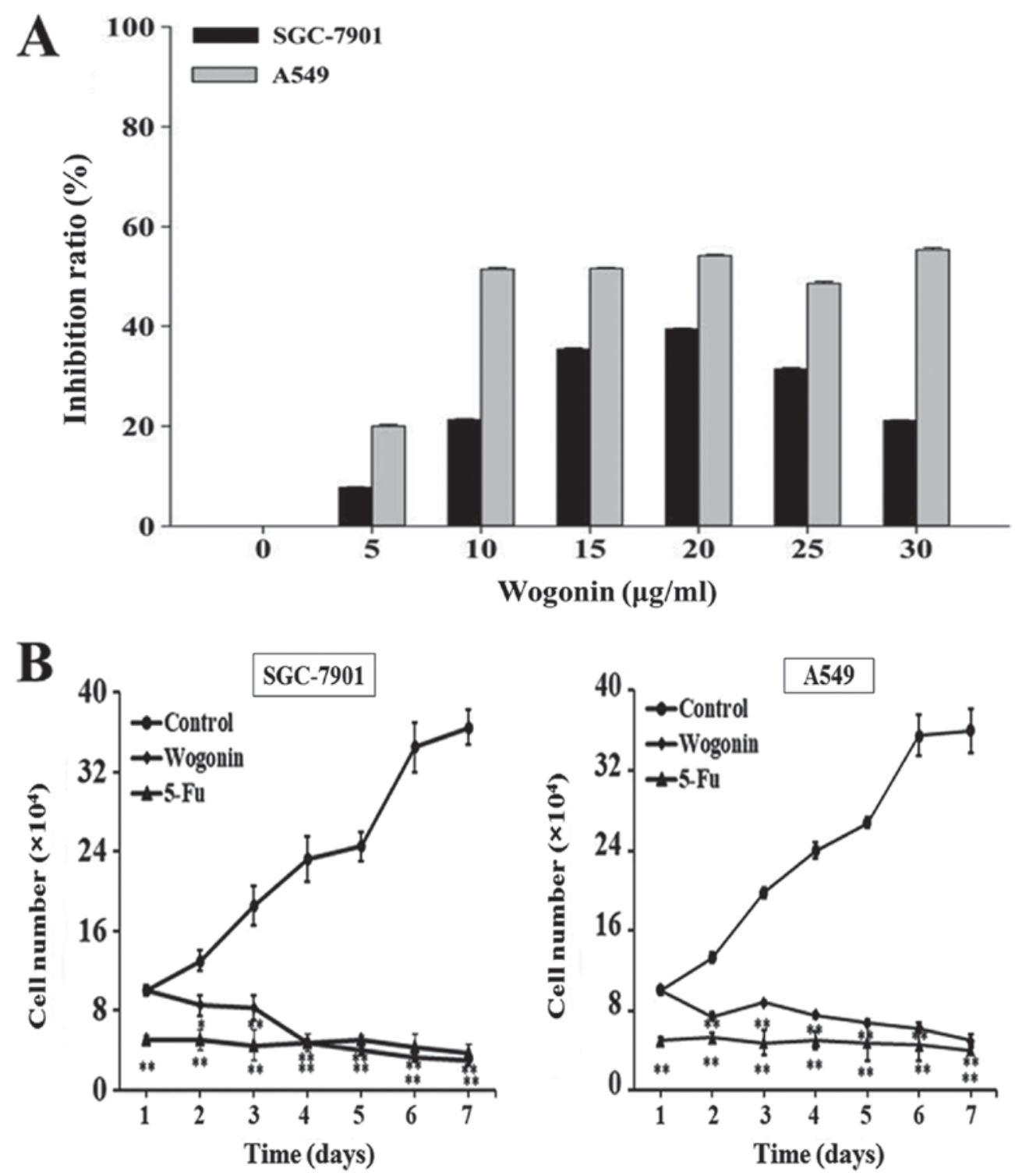

Figure 1. Effects of wogonin on cell proliferation. (A) Wogonin inhibits the proliferation rate of SGC-7901 and A549 cells. Inhibition ratios for varying amounts of wogonin were determined by MTT assay following treatment for $48 \mathrm{~h}$. (B) Growth curves of SGC-7901 and A549 cells. Cells were treated with $15 \mu \mathrm{g} / \mathrm{ml}$ wogonin and monitored over 7 days. ${ }^{*} \mathrm{P}<0.05$ and ${ }^{* *} \mathrm{P}<0.01$ vs. control; $\mathrm{n}=4$.

was demonstrated that human gastric cancer cells and human lung adenocarcinoma cells were sensitive to wogonin treatment. The inhibitory effects of wogonin on cell proliferation were evaluated and the maximal inhibitory rate was induced by $15-20 \mu \mathrm{g} / \mathrm{ml}$ wogonin, suggesting a high inhibitory efficiency on cell proliferation. Furthermore, according to the inhibitory rates exerted by wogonin $(15 \mu \mathrm{g} / \mathrm{ml})$, a stronger effect on A549 cell proliferation was observed when compared with SGC-7901 cells, thus it is necessary and essential to launch a contrastive study on the effects of wogonin in these two cell lines. Growth curves and H\&E staining results suggested that, wogonin $(15 \mu \mathrm{g} / \mathrm{ml})$ may inhibit the cell proliferation in a time-dependent manner. 5-Fu is a first-line adjuvant chemotherapeutic agent that is often administered as part of a regimen with other cytotoxic drugs, including Cisplatin. It is also a potent antitumor agent that affects pyrimidine synthesis by inhibiting thymidylate synthetase $(27,28)$. In the current study, 5-Fu was selected as a positive control to further assess the inhibitory effects of wogonin on SGC-7901 and A549 cell proliferation. The observed effects on proliferation induced by wogonin were not significantly different compared with the effects exhibited by 5 -Fu treatment.

Cancer is considered a metabolic disease, which requires a lot of energy for proliferation, metastasis, infiltration and other physiological functions (29). Even in the presence of ample oxygen, cancer cells preferentially metabolize glucose by glycolysis, which is a less efficient pathway for producing ATP when compared with oxidative phosphorylation (30). In highly proliferating tumors, blood supply may become insufficient and cancer cells are exposed to hypoxia, which may upregulate HIF-1, which in turn mediates overexpression of glycolytic enzymes and the upregulation of glucose transporters (GLUT) $(31,32)$. In addition, HIF stimulates angiogenesis by upregulating several factors, including the vascular endothelial growth factor, GLUT-1 and LDH (33-35). In tumor cells, glucose is metabolized to lactate and the 
A
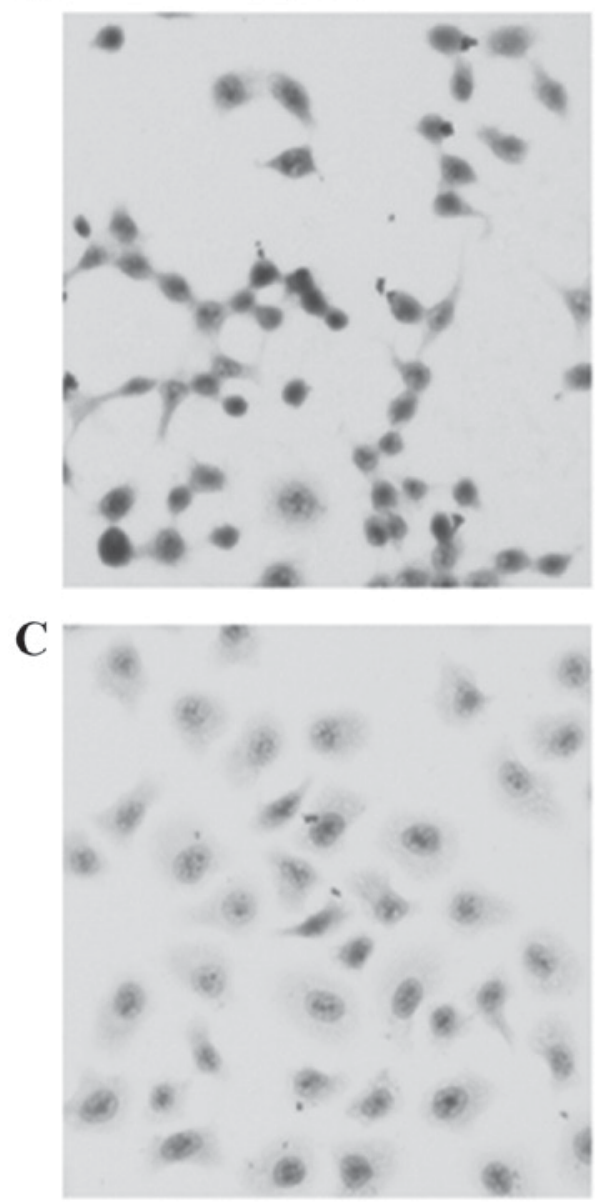

$\mathbf{E}$

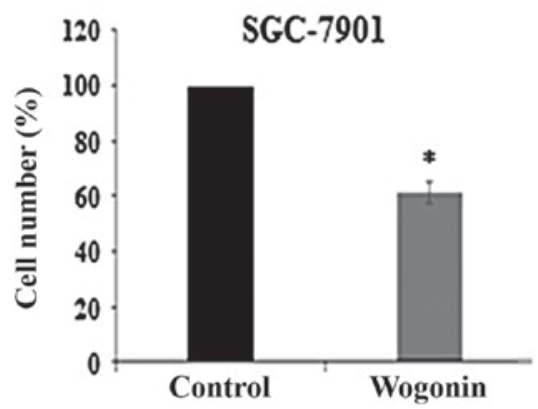

B

Wogonin

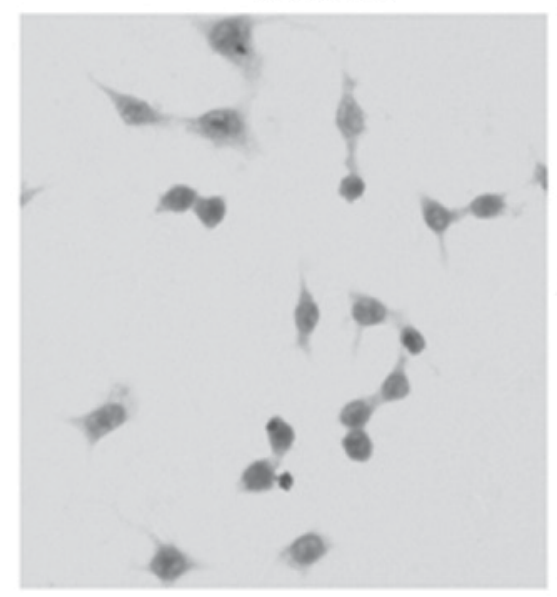

(x40)

D

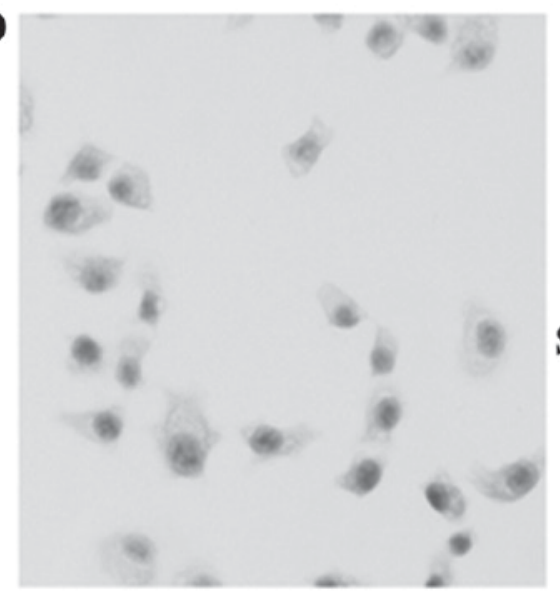

F

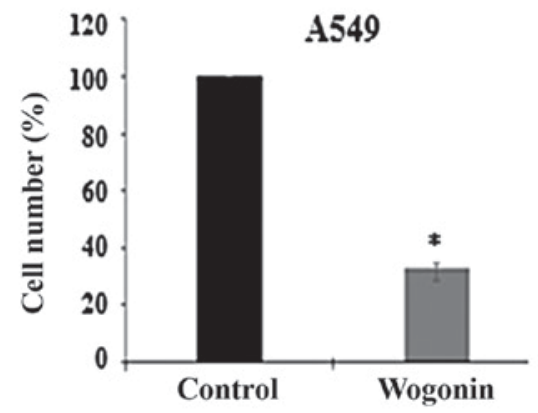

Figure 2. H\&E staining of A549 and SGC-7901 cells. H\&E staining of (A) untreated A549 cells and (B) A549 treated with wogonin (15 $\mu \mathrm{g} / \mathrm{ml}$; magnification, x40). H\&E staining of (C) untreated SGC-7901 cells and (D) SGC-7901 treated with wogonin (15 $\mu \mathrm{g} / \mathrm{ml}$; magnification, x40). Cell numbers in the control and wogonin-treated group for (E) A549 and (F) SGC-7901 cells, with the cell number in control group set as $100 \%$. "P<0.05 vs. control; n=4. H\&E, hematoxylin and eosin.

latter is exported from cells by MCT-4, which results in an accumulation of lactate, lowering the $\mathrm{pH}$ in the tumor microenvironment $(36,37)$. Tumor cells primarily perform glycolysis instead of oxidative phosphorylation and it is well known that this metabolic alteration is important for tumor development and progression and is a hallmark of cancer (38). HK and PK are two rate-limiting enzymes in the glycolysis, which catalyze the initial step of glycolysis and the dephosphorylation of phosphoenolpyruvate to pyruvate, respectively (39). LDH is a glycolytic enzyme, which catalyzes the reversible conversion of lactate to pyruvic acid, therefore contributing to the acidic microenvironment (40). SDH participates in the TAC and is located on the inner mitochondrial membrane (41). Functions of mammalian SDH extent from mitochondrial energy generation to oxygen sensing and tumor suppression (42).

In the current study, activities of three glycolytic enzymes, HK, PK and LDH, and SDH, HIF-1 $\alpha$ and MCT-4 expression, and ATP levels were measured in SGC-7901 and A549 cells treated with wogonin. Wogonin exhibited different effects in the two cell lines. In SGC-7901 cells, wogonin significantly decreased the activities of LDH and SDH, and the ATP level compared with an untreated control. In cancer progression, increasing glucose consumption leads to the accumulation of lactate, which lowers the $\mathrm{pH}$ in the tumor microenvironment (43). Wogonin may improve the acidity of the microenvironment by reducing lactate generation and 
Table I. Energy metabolism-related enzymes activities and ATP level.

\begin{tabular}{lcccr}
\hline Enzyme activity & Wogonin (SGC-7901) & Control (SGC-7901) & Wogonin (A549) & Control (A549) \\
\hline HK (U/g prot) & $49.80 \pm 5.41$ & $56.56 \pm 6.49$ & $48.61 \pm 0.41$ & $47.09 \pm 6.49$ \\
PK (U/g prot) & $2,156.56 \pm 135.61$ & $1,975.76 \pm 94.71$ & $2,507.98 \pm 191.61$ & $3,206.05 \pm 469.47$ \\
LDH (U/g prot) & $216.22 \pm 8.95 b$ & $3301.54 \pm 263.39$ & $8406.95 \pm 506.35^{\mathrm{b}}$ & $12,805.51 \pm 803.25$ \\
SDH (U/mg prot) & $239.07 \pm 6.83^{\mathrm{a}}$ & $382.46 \pm 15.89$ & $525.27 \pm 46.54$ & $511.90 \pm 36.24$ \\
ATP $(\mu$ mol/g prot) & $3,090.50 \pm 456.35^{\text {a }}$ & $4,595.84 \pm 563.52$ & $1,219.45 \pm 314.87^{\mathrm{a}}$ & $2,428.03 \pm 203.99$
\end{tabular}

Values are expressed as the mean \pm standard deviation, $\mathrm{n}=4 .{ }^{\mathrm{a}} \mathrm{P}<0.05$ and ${ }^{\mathrm{b}} \mathrm{P}<0.01$ vs. the control. HK, hexokinase; $\mathrm{PK}$, pyruvate kinase; $\mathrm{LDH}$, lactate dehydrogenase; $\mathrm{SDH}$, succinate dehydrogenase.

A

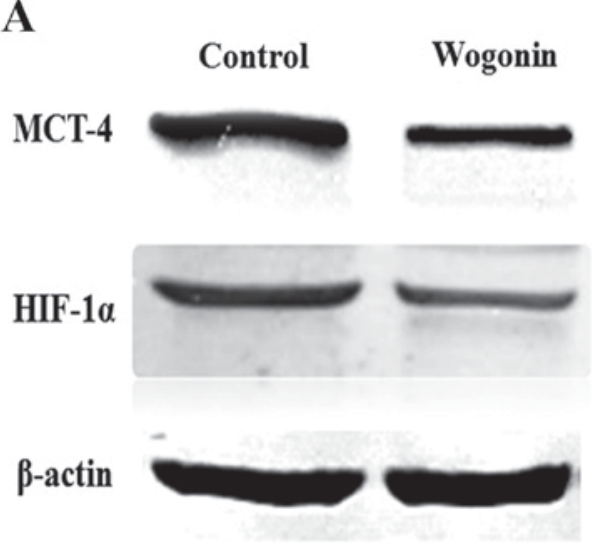

B

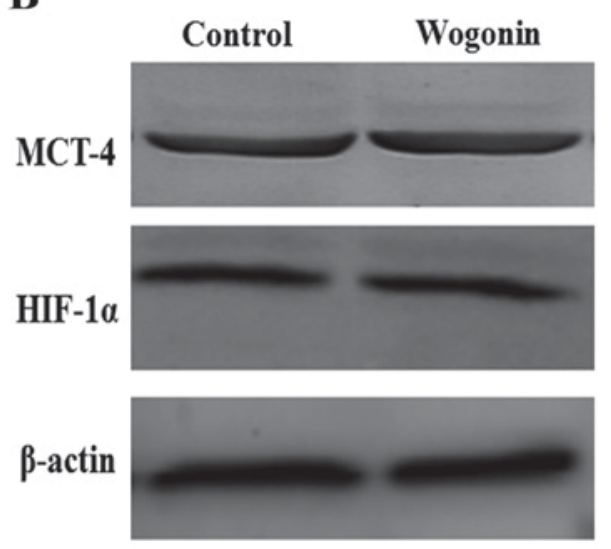

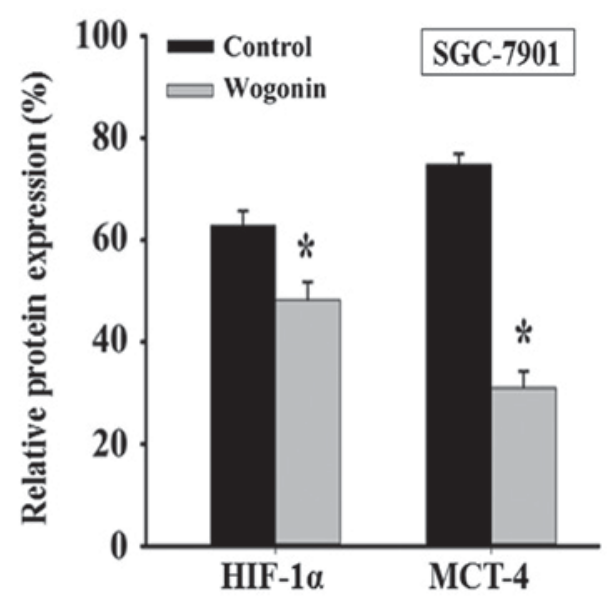

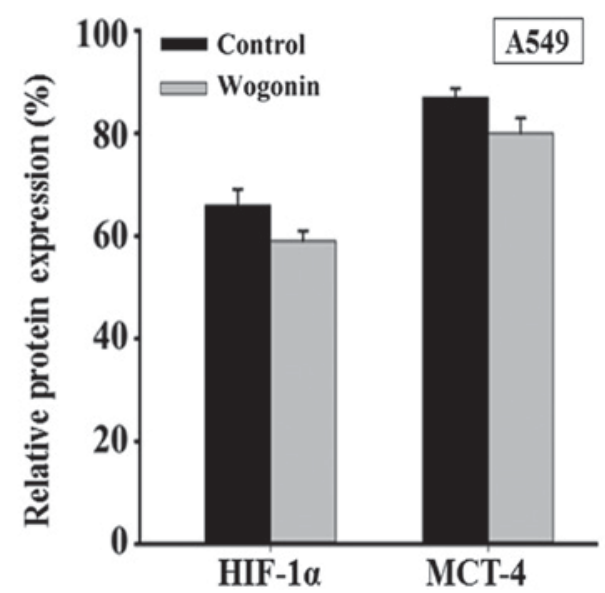

Figure 3. Effects of wogonin on HIF-1 $\alpha$ and MCT-4 expression. HIF-1 $\alpha$ and MCT-4 expression was determined in (A) SGC-7901 and (B) A549 cells treated with wogonin $(15 \mu \mathrm{g} / \mathrm{ml})$ for $48 \mathrm{~h}$. Expression levels of HIF-1 $\alpha$ and MCT-4 significantly decreased in SGC-7901 compared with the control, but not in A549. ${ }^{*} \mathrm{P}<0.05$ vs. control; $\mathrm{n}=4$. HIF-1 $\alpha$, hypoxia inducible factor- $1 \alpha$; MCT- 4 , monocarboxylate transporter- 4 .

potentially affect glycolysis through the inhibition of different glycolytic enzymes. In comparison, wogonin inhibited the activity of LDH and the generation of ATP in A549 cells, and exhibited no significant effects on activity of the other enzymes. In summary, wogonin may decrease lactic acid and ATP generation in A549 cells, but may not affect the other elements to the energy generation process.

The current study evaluated effects of wogonin on various enzymes involved in glycolysis, but only one enzyme participated in the process of aerobic oxidation. Further key enzymes, including citrate synthase, isocitrate dehydrogenase and $\alpha$-oxoglutarate dehydrogenase, involved in TAC may be analyzed in future experiments to evaluate the effects of wogonin on aerobic oxidation.

In addition, it has been suggested that the phosphatidylinositol-4, 5-bisphosphate 3-kinase (PI3K) signaling pathway serves a critical role in cancer metabolism and progression (44). The PI3K signaling pathway regulates glucose uptake via protein kinase B by regulating GLUT-1 expression, enhancing glucose capture and stimulating phosphofructokinase activity, this may cause a dependency of the cells on high levels of glucose (45). Intracellular mammalian 
target of rapamycin, which is an upstream mediator of HIF-1 activation, is further activated via the PI3K signaling pathway (46). HIF-1 activation upregulates GLUTs and HK expression in tumor cells (47). The pathways through which wogonin affected the energy metabolisms in the current study require further verification. Furthermore, in order to demonstrate the antitumor activity of wogonin and to evaluate the role wogonin serves in the energy metabolisms, tumor animal models may be established for in vivo experiments.

In summary, the findings of the present study indicated that wogonin may affect the energy metabolism and the acidic microenvironment in SGC-7901 cells by decreasing HIF-1 $\alpha$ and MCT-4 expressions. In A549 cells, wogonin exhibited no significant effects on the energy metabolism, indicating that the strong inhibitory effect of wogonin on cells proliferation may be induced by other mechanisms, but not by the inhibition of the energy metabolism. The growth of cells cannot continue without the supply of energy. While inhibiting cell proliferation, wogonin interferes with changes in certain proteins and key enzymes during cellular energy metabolism. The current study hypothesizes that the combination of wogonin and certain enzyme inhibitors in energy metabolism may prevent the supply of energy to tumor cells and therefore inhibit tumor cell proliferation.

\section{Acknowledgements}

Not applicable.

\section{Funding}

The present study was supported by the scientific research project of Harbin University of Commerce (grant no. 17XN073).

\section{Availability of data and materials}

All data generated or analyzed during this study are included in this published article.

\section{Authors' contributions}

SJW and JNZ conceived and designed the experiments of the current study. JNZ, JKZ, SR, WWS and WJZ performed the experiments. JNZ, WWS, JKZ, SR and WJZ contributed reagents/materials/analysis tools. JNZ wrote the manuscript and SW revised the manuscript. All authors read and approved the final manuscript.

\section{Ethics approval and consent to participate}

Not applicable.

\section{Patient consent for publication}

Not applicable.

\section{Competing interests}

The authors declare that they have no competing interests.

\section{References}

1. Tai MC, Shui YT, Chang LY and Xue H: Therapeutic potential of wogonin: A naturally occurring flavonoid. CNS Drug Rev 11: $141-150,2005$.

2. Huang KF, Zhuang Y, Huang YQ and Diao Y: Experimental study on inhibitory effect of wogonin on proliferation and invasion of breast cancer cells. Zhongguo Zhong Yao Za Zhi 39: 1485-1489, 2014 (In Chinese).

3. Li XD: Inhibitory effects of wogonin on lung cancer A549 cell line in vitro. J Chongqing Med Univ 7: 790-793, 2011 (In Chinese).

4. Ding J, Polier G, Köhler R, Giaisi M, Krammer PH and Li-Weber M: Wogonin and related natural flavones overcome tumor necrosis factor-related apoptosis-inducing ligand (TRAIL) protein resistance of tumors by down-regulation of c-FLIP protein and up-regulation of TRAIL receptor 2 expression. J Biol Chem 287: 641-649, 2012.

5. Hong ZP, Wang LG, Wang HJ, Ye WF and Wang XZ: Wogonin exacerbates the cytotoxic effect of oxaliplatin by inducing nitrosative stress and autophagy in human gastric cancer cells. Phytomedicine 39: 168-175, 2018.

6. Lu X, Wu XL, Li Y, Peng Y and Chen PF: Inhibitory effect of wogonin on gastric cancer SGC 7901 cell line in vitro. J Chin Pharm Sci 46: 512-517, 2011.

7. Bauman S, Fas SC, Giaisi M, Müller WW, Merling A, Gülow K, Edler L, Krammer PH and Li-Weber M: Wogonin preferentially kills malignant lymphocytes and suppresses T-cell tumor growth by inducing PLCC1 and $\mathrm{Ca}^{2+}$ dependent apoptosis. Blood 11: 2354-2363, 2008.

8. Lin CM, Chang H, Chen YH, Wu IH and Chiu JH: Wogonin inhibits IL6 induced angiogenesis via downregulation of VEGF and VEGFR-1, not VEGFR-2. Planta Med 72: 1305-1312, 2006.

9. Lu N, Gao Y, Ling Y, Chen Y, Yang Y, Gu HY, Qi Q, Liu W, Wang XT, You QD and Guo QL: Wogonin suppresses tumor growth in vivo and VEGF induced angiogenesis through inhibiting tyrosine phosphorylation of VEGFR-2. Life Sci 82: 956-963, 2008

10. Wang HW, Lin CP, Chiu JH, Chow KC, Kuo KT, Lin CS and Wang LS: Reversal of inflammation as sociated dihydrodiol dehydrogenases (AKR1C1 and AKR1C2) overexpression and drug resistance in nonsmall cell lung cancer cells by wogonin and chrysin. Int J Cancer 120: 2019-2027, 2007.

11. Chow KC, Lu MP and Wu MT: Expression of dihydrodiol dehydrogenase plays important roles in apoptosis and drug resistance of A431 squamous cell carcinoma. J Dermatol Sci 41: 205-212, 2006.

12. Penning TM, Jin Y, Steckelbroeck S, Lanisnik Rizner T and Lewis M: Structure function of human 3 alpha-hydroxysteroid dehydrogenases: Genes and proteins. Mol Cell Endocrinol 215: 63-72, 2004.

13. Zhang HW, Yang Y, Zhang K, Qiang L, Yang L, Yang L, Hu Y, Wang XT, You QD and Guo QL: Wogonin induced differentiation and G1 phase arrest of human U-937 leukemia cells via PKC delta phosphorylation. Eur J Pharmacol 591: 7-12, 2008.

14. Cho J and Lee HK: Wogonin inhibits excitotoxic and oxidative neuronal damage in primary cultured rat cortical cells. Eur J Pharmacol 485: 105-110, 2004

15. Ma SC, Du J, But PP, Deng XL, Zhang YW, Ooi VE, Xu HX, Lee SH and Lee SF: Antiviral Chinese medicinal herbs against respiratory syncytial virus. J Ethnopharmacol 79: 205-211, 2002.

16. Xiao WM, Bu P and Gong WJ: Advance in studies on antitumor and immunomodulatory effects of wogonin. Zhongguo Zhong Yao Za Zhi 39: 3004-3009, 2014 (In Chinese).

17. Cantor JR and Sabatini DM: Cancer cell metabolism: One hallmark, many faces. Cancer Discov 2: 881-898, 2012.

18. Warburg O, Wind $\mathrm{F}$ and Negelein E: The metabolism of tumors in the body. J Gen Physiol 8: 519-530, 1927.

19. Hanahan D and Weinberg RA: The hallmarks of cancer. Cell 100: 57-70, 2000.

20. Dong B and Zhu YM: Molecular-tareted therapy for cancer. Chin J Cancer 29: 340-345, 2010.

21. Koppenol WH, Bounds PL and Dang CV: Otto Warburg's contributions to current concepts of cancer metabolism. Nat Rev Cancer 11: 325-337, 2011.

22. Batool S, Joseph TP, Hussain M, Vuai MS, Khinsar KH, Din SRU, Padhiar AA, Zhong M, Ning A, Zhang W, et al: LP1 from Lentinula edodes C91-3 induces autophagy, apoptosis and reduces metastasis in human gastric cancer cell line SGC-7901. Int J Mol Sci 19: pii: E2986, 2018. 
23. Park YJ, Lee SR, Kim DM, Yu JS, Beemelmanns C, Chung KH and Kim KH: The inhibitory effects of cyclodepsipeptides from the entomopathogenic fungus beauveria bassiana on myofibroblast differentiation in A549 alveolar epithelial cells. Molecules 23: pii: E2568, 2018.

24. Longley DB, Harkin DP and Johnston PG: 5-Fluorouracil: Mechanisms of action and clinical strategies. Nat Rev Cancer 3: 330-338, 2003

25. Kim EH, Shim B, Kang S, Jeong G, Lee JS, Yu YB and Chun M: Anti-inflammatory effects of Scutellaria baicalensis extract via suppression of immune modulators and MAP kinase signaling molecules. J Ethnopharmacol 126: 320-331, 2009.

26. Wang M, Zhao X, Zhu D, Liu T, Liang X, Liu F, Zhang Y, Dong X and Sun B: HIF-1 $\alpha$ promoted vasculogenic mimicry formation in hepatocellular carcinoma through LOXL2 up-regulation in hypoxic tumor microenvironment. J Exp Clin Cancer Res 36: 60, 2017.

27. Shirota Y, Stoehlmacher J, Brabender J, Xiong YP, Uetake H, Danenberg KD, Groshen S, Tsao-Wei DD, Danenberg PV and Lenz HJ: ERCC1 and thymidy-late synthase mRNA levels predict survival for colorectal cancer patients receiving combination oxaliplatin and fluorouracil chemotherapy. J Clin Oncol 19: 4298-4304, 2001.

28. de Gramont A, Figer A, Seymour M, Homerin M, Hmissi A, Cassidy J, Boni C, Cortes-Funes H, Cervantes A, Freyer G, et al: Leucovorin and fluorouracil with or without oxaliplatin as first-line treatment in advanced col-orectal cancer. J Clin Oncol 18: 2938-2947, 2000.

29. Hsu PP and Sabatini DM: Cancer cell metabolism: Warburg and beyond. Cell 134: 703-707, 2008.

30. Bartrons R and Caro J: Hypoxia, glucose metabolism and the Warburg's effect. J Bioenerg Biomembr 39: 223-229, 2007.

31. Zhang BY, Qu QX and Gu AK: Expression and clinical significance of CD147, MCT4 in cervical lesions. J Int Obstet Gynecol 42: 194-196, 2015.

32. Pietras A, Johnsson AS and Påhlman S: The HIF-2 $\alpha$-driven pseudo-hypoxic phenotype in tumor aggressiveness, differentiation, and vascularization. Curr Top Microbiol Immunol 345: $1-20,2010$

33. Wolf A, Agnihotri S, Micallef J, Mukherjee J, Sabha N, Cairns R, Hawkins $\mathrm{C}$ and Guha A: Hexokinase 2 is a key mediator of aerobic glycolysis and promotes tumor growth in human glioblastoma multiforme. Cell 208: 313-326, 2011.

34. Chen J, Xie J, Jiang Z, Wang B, Wang Y and Hu X: Shikonin and its analogs inhibit cancer cell glycolysis by targeting tumor pyruvate kinase-M2. Oncogene 30: 4297-4306, 2011.
35. Trufelli DC, Moraes TV, Lima AA and Giglio AD: Epidemiological profile and prognostic factors in patients with lung cancer. Rev Assoc Med Bras (1992) 62: 428-433, 2016.

36. Kroemer $\mathrm{G}$ and Pouyssegur J: Tumor cell metabolism: Cancers Achilles heel. Cancer Cell 13: 472-482, 2008.

37. Fukumura D, Xu L, Chen Y, Gohongi T, Seed B and Jain RK: Hypoxia and acidosis independently upregulate vascular endothelial growth factor transcription in brain tumors in vivo. Cancer Res 61: 6020-6024, 2001

38. Hanahan D and Weinberg RA: Hallmarks of cancer: The next generation. Cell 144: 646-674, 2011.

39. Chan AK, Bruce JI and Siriwardena AK: Glucose metabolic phenotype of pancreatic cancer. World J Gastroenterol 22: 3471-3485, 2016

40. Mansouri S, Shahriari A, Kalantar H, Moini Zanjani T and Haghi Karamallah M: Role of malate dehydrogenase in facilitating lactate dehydrogenase to support the glycolysis pathway in tumors. Biomed Rep 6: 463-467, 2017.

41. Ghezzi D, Goffrini P, Uziel G, Horvath R, Klopstock T, Lochmüller H, D'Adamo P, Gasparini P, Strom TM, Prokisch $\mathrm{H}$, et al: SDHAF1, encoding a LYR complex-II specific assembly factor, is mutated in SDH-defective infantile leukoencephalopathy. Nat Genet 41: 654-656, 2009.

42. Pecsi I, Hards K, Ekanayaka N, Berney M, Hartman T, Jacobs WR $\mathrm{Jr}$ and Cook GM: Essentiality of succinate dehydrogenase in Mycobacterium smegmatis and its role in the generation of the membrane potential under hypoxia. MBio 5: pii: e01093-14, 2014.

43. Pucino V, Cucchi D and Mauro C: Lactate transporters as therapeutic targets in cancer and inflammatory diseases. Expert Opin Ther Targets 22: 735-743, 2018.

44. Han K, Xu X, Chen G, Zeng Y, Zhu J, Du X, Zhang Z, Cao B, Liu Z and Mao X: Identification of apromising PI3K inhibitor for the treatment of multiple myeloma throughthe structural optimization. J Hematol Oncol 7: 9, 2014.

45. Wallace DC: Mitochondria and cancer: Warburg addressed. Cold Spring Harb Symp Quant Biol 70: 363-374, 2005.

46. Hudson CC, Liu M, Chiang GG, Otterness DM, Loomis DC, Kaper F, Giaccia AJ and Abraham RT: Regulation of hypoxiainducible factor 1alpha expression and function by the mammalian target of rapamycin. Mol Cell Biol 22: 7004-7014, 2002.

47. Semenza GL: HIF-1: Upstream and downstream of cancer metabolism. Curr Opin Genet Dev 20: 51-56, 2010. 